Review Paper

\title{
THE POSITION OF WOMEN IN THE SERBIAN ARMY: CURRENT STATE OF AFFAIRS AND PERSPECTIVES
}

\author{
UDC 355.11-055.2(497.11)
}

\section{Filip Mirić}

Faculty of Law, University of Niš, Niš, Republic of Serbia

\begin{abstract}
The military profession has always been regarded as a typical male profession. This conception is the result of numerous prejudices about the ability of women to adequately respond to all the challenges in this service. In the past, there seemed to be no place for women in the Serbian Army. Women who wanted to serve their homeland in this way were forced to conceal their gender identity. The most prominent example is the First World War heroine Milunka Savić, whose true identity would have probably remained undetected if she had not been wounded. The paper deals with the position of women in the Serbian Army today, problems they encounter and the prospects for resolving them. The Serbian Armed Forces have made an important step towards a greater involvement of women in their ranks by enabling women participation in the army as officers, non-commissioned officers and professional soldiers, in the same way as men. The aim of the paper is to point out to the directions of the development of the position of women in the Serbian Army. especially considering the process of its professionalisation.
\end{abstract}

Key words: women, Serbian Army, professionalization

\section{INTRODUCTION}

The position of women in the social structure is certainly one of the current topics in the contemporary society. Gender equality is one of the principles of modern democracy, and the best evidence of such a democracy is the status of women in all social structures of the community, especially in the armed forces. When speaking about democracy and the Serbian armed forces, it should be noted that the most significant step towards instituting higher standards of gender equality in the security sector was the decision to enhance the admission of women into professional military service (by increasing the percentage of their representation in the overall composition of the Army and extending the scope of their professional services) and to institute military education for women at the Military

Received May $7^{\text {th }}, 2019 /$ Accepted June $6^{\text {th }}, 2019$

Corresponding author: Filip Mirić, LL.D., Research Fellow, Senior Associate for Postgraduate Study Services, Faculty of Law, 11 Trg kralja Aleksandra, 18000 Niš, Republic of Serbia; E-mail: filip@prafak.ni.ac.rs 
Academy. In this way, the state has tried to avoid the phenomenon of the 'glass ceiling', which refers to the invisible barriers that prevent the advancement of women in organizations and stop them at a certain level (Miladinović, 2013: 272).

The army is the pillar of security in every state. The security of the state and all its citizens depends on the efficiency and training of its armed forces. The military profession has always been regarded as a typically male profession. This conception is the result of numerous prejudices about the ability of women to adequately respond to all the challenges in this service. In the past, there seemed to be no place for women in the Serbian Army. In the past, it seems that there was no place for women in the Serbian army. Women who wanted to serve their homeland in this way were forced to conceal their gender and gender identity. The most prominent example is the First World War heroine Milunka Savić, whose true identity would have probably remained undetected if she had not been wounded.

The paper deals with the position of women in the Serbian Army today, problems they encounter and the prospects for resolving them. The Serbian Armed Forces have made an important step towards a greater involvement of women in their ranks by enabling women's participation in the army as officers, non-commissioned officers and professional soldiers, in the same way as men. The aim of the paper is to point out to the directions of the development of the position of women in the Serbian Army, especially considering the process of its professionalisation. It should be noted that the contemporary laws in a number of countries have contributed to changing the long-standing custom, reflected in the traditional absence of women from the armed forces. The envisaged normative framework, including the anti-discriminatory regulation of the labour market and the paradigm shift from obligatory recruitment to a voluntary army service, has enabled women to enter the army and military forces (Mršević, Janković, 2017: 77).

\section{WOMEN IN FOREIGN ARMED FORCES}

Increasing women's participation in the armed forces usually occurred during war conflicts, most frequently because men were involved in direct combat. In times of war, women usually performed civilian jobs in the armed forces (medical care, stewardship, general supply and quartermaster services, etc.). The endeavours aimed at enabling women to perform the duties of officers and to directly participate in battles against the enemy as combatants (under the same conditions as men) were closely related to the general tendency to combat gender discrimination in the area of labor and employment. This part of the paper will briefly present the experiences of the United States, Sweden and Israel in the process of involving women and enhancing their participation in the military services. These comparative practices may serve as guidelines for enhancing the position of women in the Serbian Army, especially considering the process of its professionalisation.

\section{The United States of America}

Women currently account for about $13 \%$ of the United States Army. There is no doubt that women have successfully entered the military hierarchy and assumed positions that would be difficult to imagine only a decade ago. They have also proved that they have the necessary skills to serve in command positions in the armed forces. A large number of women in the United States served in the armed forces during the Second 
World War. They were assigned to different military units and departments but they were barred from engaging in direct combat. Many of them performed unusual civilian jobs for the needs of the armed forces, working as parachute packers, aviation mechanics, artillery instructors, etc. Although women were grouped into several working categories, the given circumstances and warfare needs opened up other jobs for them. During the war, the need for personnel was the main factor that contributed to expanding the women's role and position in the army, but other significant factors were women's patriotisms and desire to contribute to the war efforts of their country, as well as their pressure to make their war contributions officially recognized.

After the war, the US authorities were bound to consider the issue of the future role of women in the army. In 1948, in the same year when President Truman enabled racial integration, Congress adopted the Women's Armed Services Integration Act, which enabled women to serve as regular members of the armed forces (Mršević and Janković, 2017: 83).

\section{Sweden}

Until 1980, the military profession in Sweden was reserved exclusively for men, and the issue of women in the military profession was the subject of political debate for much of the $20^{\text {th }}$ century. In 1969, the commander-in-chief of the aviation requested the permission from the King of Sweden to employ women in military positions in the Air Force department. The initiatives for employing women came from the military structures but also from the Government, which called upon the consistent application of Swedish gender equality policies. The request of the aviation commander was motivated by the lack of manpower in aviation, rather than the desire to achieve gender equality. The idea was that women should be employed in non-combat positions, which would enable men to participate in combat operations. The Defense Minister claimed that military officers should have the same status as other state officials, and gender identity should not be ground for exclusion of women. The focus on removing formal gender impediments, the effects of Swedish laws and policies on equal opportunities, and the pressure to enhance gender equality in the structural organization of armed forces has proven to be a successful combination.

When the first Swedish woman entered the military profession in 1980, the Equal Opportunities Act regulated the Swedish labor market. The aim of this legislative act was to promote gender equality rights in terms of equal employment opportunities, treatment and working conditions for both men and women. The subsequent Equal Opportunities Act of 2005 was primarily aimed at improving women's working conditions. Enabling women to enter the military profession was considered to be the practice of inclusion, which would gradually eliminate firmly set gender-based barriers. The restrictions were ultimately removed in 1989, and by the year 2000 women entered different military units as officers, commanders of tank units, navy-ship captains and fighter-aircraft pilots (Mršević and Janković, 2017: 88). Sweden is an example of a country where women are properly included in the defense forces.

\section{Israel}

Engagement of women for the needs of Israeli defense forces is a direct consequence of the complex security situation in this country, due to ongoing attacks in the Gaza region. In the last few years, the Israeli Defense Forces (IDF) have drawn the attention of the world public by the substantial integration of women's in the armed forces, enhancing 
their prospects of advancement and improving the overall status of Israeli women in the army (Mršević and Janković, 2017: 90). In the IDF, the role of a combatant is among the most respected social roles and a prestigious status symbol; as such, it entails privileges which are transferrable to civilian life, considering that the quality of civilian career largely depends on the importance of military roles performed during military service and the assessment of overall performance (Mršević and Janković, 2017: 91). It has been noted that women in the Israeli Defense Forces greatly contribute to raising the fighting morale of the army, which is by no means insignificant, considering the tasks of armed forces and their reputation in society.

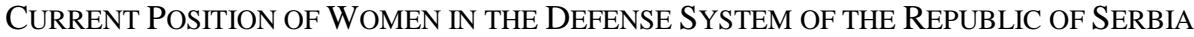

In the Kingdom of Serbia, women had a significant role in the armed forces, particularly in times of war. Historical facts provide evidence about the highest combat values and dedication of the combat units exclusively composed of volunteers, including female volunteers who directly participated in warfares. This practice was also prominent during the Second World War among the female members of the liberation movement. These examples speak in favour of voluntarism as a motive for serving in modern armed forces. In this regard, it is suggested that the volunteering tradition should be used in the contemporary social circumstances as a model of good practice for recruiting personnel for the professional army in the Republic of Serbia. It is concluded that the phenomenon of volunteerism is affirmative, regardless of the deeper motivation that initiates the citizen to join the military and the armed forces in democratic societies (Barović, 2010: 348).

Today, the Republic of Serbia is an active member of the United Nations (UN), the Organization for Security and Co-operation in Europe and the Partnership for Peace (OSCE), as well as a candidate for potential membership in the European Union. As such, Serbia has recognized different international documents and good practices (stemming from the activities of international institutions and/or the civil society sector) which emphasize the importance of equal participation of men and women in preventing and resolving conflicts, promoting the culture of lasting and sustainable peace in society, and ensuring equal opportunities without gender-based discrimination. Consequently, these commitments were incorporated into the content of the National Action Plan for the implementation of UN Security Council Resolution 1325 in the Republic of Serbia for the period from 2010 to 2015 (Stojković, 2014: 46).

Article 11 of the Military Act of the Republic of Serbia stipulates that the provisions on the composition of the Serbian Armed Forces equally apply to women and men. ${ }^{1}$ Thus, the normative framework reinforces the importance of respecting the principle of equality of men and women in the service of the Serbian Armed Forces.

The current status of women in the Serbian Armed Forces has not been the subject of substantial scientific research. There is only a small number of articles on this issue. The available literature shows that stereotypes about male soldiers had prevailed in the traditional Serbian mindset for centuries. In the past, the army service was exclusively intended for men, and women had no place there. When women were eventually allowed to enter the army ranks, they mainly performed secondary (non-combatant) duties, in

${ }^{1}$ Zakon o vojsci Srbije (Military Act of the Republic of Serbia), "Službeni glasnik RS", 116/2007...36/2018 . 
most cases behind the front line. However, the situation gradually changed over time. The Second World War was marked by the mass presence of women in the regular armies, especially in the composition of the liberation movements throughout the world (Šaranović, Marček and Kilibarda, 2005). When the war ended, the total number of armed forces was reduced and a large number of women returned to their civilian ("female") jobs. However, their representation in the army did not significantly decrease. In fact, there was a trend of a constant increase of women's engagement in the army, and their presence was more and more visible both in non-combat and combat units, both in the backlines and in the frontlines. In the $21^{\text {st }}$ century, creating a more favorable climate for equalizing the laborrelated rights and duties of men and women in the area of defense has become one of the essential prerequisites for achieving gender equality. By accepting the concept of gender equality as one of its strategic commitments, the Army of Serbia has been committed to attaining the highest standards in the area of gender equality in its ranks (Šaranović and Kilibarda, 2011).

As compared to young men, women show more interest in logistics and less interest in being deployed with the land (ground) forces, which is rather expected considering the stereotypical division into "male" and "female" jobs, whereby the operations of officers in the land forces are considered to be "typically male". There is no dispute that duties of officer in the land forces are more physically demanding in comparison to duties in other military forces, which is a crucial factor in women's decision to pursue education at the Military Academy. Concurrently, their increased interest in logistics indicates that they probably take into account the specific duties they will be performing in the military as well as the prospective employment opportunities outside the army infrastructure, in case they are forced to leave the military profession before the expiry of the term of employment in the army. A professional degree in logistics obtained from the Military Academy certainly provides better employment opportunities than a degree in land forces.

One of the key conditions for women's integration into the Serbian Army organizational structure is adaptability, which can be illustrated by the "drop-out" rate of female cadets during their education at the Military Academy. This rate is a general indicator of their adjustment or non-adjustment to the conditions of life in the military environment and the strict requirements of the educational process at the Military Academy. As noted by Šaranović (2011), the research data covering the educational process of several generations of female cadets show that the first generation of female cadets experienced problems in adapting to the new environment but but that the situation eventually improved in subsequent generations. Namely, out of 30 women admitted the Military Academy in 2007, 11 female cadets $(36.7 \%)$ did not continue education with their generation in the next academic year; one cadet had to leave school due to illness, while as many as 10 cadets (33 $\%$ ) could not enroll for the second year of study because they did not pass the required exams within the stipulated deadline. After taking the exams in an additionally approved exam term, nine (out of these 10) cadets continued their education with the next generation. The situation in the generation admitted in 2008 and 2009 was considerably more favourable. In 2008, only two out of 32 admitted female cadets were discharged (one for illness and one for low performance grades). In the generation admitted in 2009, only two out of 49 admitted cadets were discharged (one for illness and one at her own request) (Šaranović, 2011: 124). Such a significant decrease in the drop-out rate may be attributed to the fact that the number of applicants for the Military Academy exceeded the projected 
admission quota, which made the admission process more competitive and enabled the selection of the best candidates.

Although physical strain is often viewed to be one of the limiting factors in for women, the same survey shows that engagement of women in military duties is not a particular problem for most cadets $(67.50 \%)$, while additional $20 \%$ of female cadets could not decide whether to qualify physical training as difficult or not. The military marching drill, weapons training, and wearing uniforms are seldom perceived as heavy duty (only 5\% of female cadets encountered problems there). In this respect, there are no significant differences between men and women. Women often encounter the problem of adapting to the living and working conditions but their accommodation and adjustment to life in the Serbian armed forces is facilitated by the opportunity to take part in extracurricular activities. The survey shows that $72.50 \%$ of surveyed female cadets enjoyed the "opportunity to engage in sports activities"; $55 \%$ of respondents pointed to "the spirit of friendship and camaraderie" and $35 \%$ of surveyed female cadets expressed interest in "cultural and entertainment activities". These were the top-three factors that female cadets considered important in the adaptation process. Notably, they also proved to be the top-three factors in the survey conducted among male cadets, which is an additional confirmation of their significance for the successful adaptation to the conditions of education at the Military Academy (Šaranović, 2011: 126). It further suggests that special attention should be paid to these aspects of pedagogical environment, especially in the initial stages of education which prove to be most critical

The survey also shows that slightly more than half of the female cadets $(51.28 \%)$ would make the same choice to pursue their education at the Military Academy, while $20 \%$ of respondents were not sure whether they would make the same decision if they were in a position to choose their prospective education again. A total of $28 \%$ of the surveyed female cadets noted that they would not pursue military education. The data indisputably indicate that there are difficulties and specific deterrents that female cadets encounter in the process of adapting to the living and working conditions at the Military Academy. They seem to be questioning their choice of military career much more frequently than male cadets. Only $6 \%$ of male cadets responded that they would not opt to continue their education at the Military Academy if they were to choose again. The presented data suggest that that the female cadets' expectations from the Military Academy were significantly different from what they experienced "on the ground" (Šaranović, 2011: 127).

The presented data generate the key question: is gender equality the decisive factor, and are there other (normative, institutional, social and psychological) factors that may contribute to overcoming the discrepancy between the male and female perceptions about the military career and the Serbian armed forces?

Based on the results of the extensive research conducted in the Serbian Army by using the Scale for the assessment of gender stereotypes, it was concluded that gender stereotypes exist in the Serbian Army, that the existence of gender stereotypes is not conditioned and determined by the person's gender, and that men and women assess the characteristics of their own gender as being similar to the characteristics of successful officers in the leadership position, irrespective of their gender (Višacki, 2016: 181). 


\section{CONCLUSION}

The position of women in the armed forces has changed through history, largely depending on gender stereotypes. For centuries, the military profession was exclusively reserved for men. In times of war, women commonly performed civilian jobs in the armed forces. When they were eventually allowed to enter the army, they mainly performed noncombatant tasks and provided logistic services. The turning point was the Second World War when women were directly involved in military operations and performed important duties in the liberation movements throughout the world. Their position was significantly changed after the war, and particularly after the recognition of different international documents aimed at ensuring equal opportunities without gender-based discrimination.

In recent years, the Serbian Armed Forces have made an important step towards a greater involvement and representation of women in the army by enhancing their participation in the military services as officers, non-commissioned officers and professional soldiers. The paper presents the results of the existing research on the position of women in the Serbian Army. The research shows that women encounter numerous challenges in the course of military education, training and professional service, in the same way as men. Nowadays, women seem to have adapted to the living and working conditions in the armed forces. In the context of professionalization of the Serbian army, they are considered to have a significant role in the defense system of the Republic of Serbia.

The envisaged normative framework and anti-discriminatory regulation of the labour market have provided conditions for equal participation of women in the Serbian armed forces. Through their active participation and performance of combat and non-combat tasks, women in the Serbian Army demonstrate that they are ready to respond to all the challenges of their military career.

\section{REFERENCES}

Barović, V. (2010) Dobrovoljno učešće u oružanim snagama Kraljevine Srbije kao mogući model profesionalizacije oružanih snaga Republike Srbije (Voluntary participation in the Armed Forces of the Kingdom of Serbia as a model of profesionalisation of the Armed Forces of the Republic of Serbia), Vojno delo, vol. 62, no. 2, pp. 348-360.

Miladinović, I. (2013) Samoprocena usklađenosti uloga žena u vojnoj profesiji (Self-assessment of women's roles in the military services), Vojno delo, vol. 65, no. 4, pp. 272-290.

Mršević, Z. and Janković, S. (2017) Učešće žena u oružanim snagama savremenog doba (Participation of women in modern military forces), Strani pravni život, vol. 61, no. 1, pp. 77-94.

Stojković, B. (2014) Rezultati unapređenja rodne ravnopravnosti u nacionalnom sistemu bezbednosti u Republici Srbiji (The effects of enhancing gender equality in the national security system of the Republic of Serbia), Bezbednost, vol. 56, no. 2, pp. 32-49.

Šaranović, J. (2011) Rodna ravnopravnost u Vojsci Srbije - između diktata prošlosti i izazova budućnosti (Gender equality in the Serbian Army- in the midst of the past dictates and future challenges), Vojno delo, vol. 63 , no. 1 , pp. 108-135.

Šaranović, J. and Kilibarda, Z. (2011) U korak s vremenom: Ministarstvo odbrane $i$ Vojska Srbije na putu objektivizacije rodne ravnopravnosti (In step with the time: Ministry of Defense and Serbian Armed Forces on the road to gender equality objectification), Beograd: Institut za strategijska istraživanja.

Šaranović, J., Marček, J. and Kilibarda, Z. (2005) Obim i modaliteti angažovanja žena u savremenim armijama (Scope and models of women's participation in contemporary armed forces), Beograd: Institut ratne veštine.

Višacki, Tatjana (2016). Socijalno-psihološki aspekti procesa ostvarivanja rodne ravnopravnosti u Vojsci Srbije (Social and Phychological Aspects of the process of exercising gender equality in the Serbian Armed Forces), Doktorska disertacija, Fakultet političkih nauka, Univerzitet u Beogradu, Beograd 2016. http://www.fpn.bg.ac.rs/arhiva/sites/default/files/ docs/tatjana_visacki_disertacija_fpn.pdf(accessed on 29 April 2019)

Zakon o vojsci Srbije (Military Act of Republic of Serbia), "Službeni glasnik RS", 116/2007...36/2018). 


\section{POLOŽAJ ŽENA U VOJSCI SRBIJE - STANJE I PERSPEKTIVE}

Vojnička profesija je oduvek smatrana tipično muškom profesijom. Ovakvo shvatanje je posledica brojnih predrasuda o mogućnosti žena da adekvatno odgovore svim izazovima koje bavljenje ovim pozivom nosi sa sobom. U prošlosti, kao da nije bilo mesta za žene u vojsci Srbije. Žene koje su želele da na ovaj način služe svojoj otadžbini su bile prinuđene da prikrivaju svoj rodni i polni identitet. O tome svedoči i primer heroine Prvog svetskog rata, Milunke Savić, čiji bi pravi identitet verovatno ostao neotkriven da nije bila ranjena. Rad se bavi položajem žena u vojsci Srbije danas, poblemima sa kojima se one suočavaju i perspektivama za njihovo rešavanje. Vojska Srbije je učinila važan iskorak ka većem uključivanju žena u svoje redove, onda kada je odobeno da i lica ženskog pola mogu da budu angažovani na poslovima oficira, podoficira i profesionalnih vojnika, na isti način kao i lica muškog pola. Cilj rada je da ukaže na pravce razvoja položaja žena u Vojsci Srbije, posebno imajući u vidu proces njene profesionalizacije.

Ključne reči: Vojska Srbije, profesionalizacija

Proofreading and copy-editing:

Gordana Ignjatovic 